\title{
A munkaeröpiaci hátrányok területi vonatkozásai Észak-Magyarországon
}

\section{Spatial aspects of labour market disadvantages in Northern Hungary}

Siposné A munkaerőpiaci hátrányok (munkanélküliség, Nándori Eszfer inaktivitás) makro- és mikroszinten számos negatív Miskolci Egyetem következménnyel járnak. A tanulmány a munkanélE-mail: küliség alakulásában fellelhetô területi hatásokat mustsne@uni-miskolc.hu tatja be. Egyrészt vizsgálja a régió települései között fennálló autokorreláció meglétét, másrészt a munkanélküliség alakulását befolyásoló tényezőket. A 2014-re vonatkozó autokorrelációs vizsgálat a régió északi részén néhány hot spotot, déli részén in-

Kulcsszavak: kább cold spotokat tárt fel. Az OLS regressziómunkanélküliség, számítás következtetése, hogy gazdasági (gazdasági Moran I, növekedés, az iparban foglalkoztatottak aránya) és Észak-Magyarország, demográfiai (a 60 éves és idősebb népesség aránya, aktivitás, a gazdaságilag aktív nők aránya) tényezők befolyáautokorreláció solják szignifikánsan a munkanélküliség alakulását. 
Labour market disadvantages (unemployment, inactivity) have several negative consequences both at the macro and at the micro levels. The paper examines the spatial effects in the trends of unemployment. On the one hand, it deals with the autocorrelation among the settlements of the region. On the other, it examines the factors influencing unemployment. The autocorrelation analysis carried out for 2014 revealed some hot spots in the northern part of the region and some

Keywords: cold spots in the southern part. The conclusion of unemployment, the OLS regression is that unemployment is Moran I, influenced significantly by economic (economic Northern Hungary, growth, share of employed in the industrial sector) activity, and demographic factors (population older than autocorrelation 60, share of active women).

Beküldve: 2016. január 31.

Elfogadva: 2016. június 28.

\section{Bevezetés}

A munkaerőpiaci hátrányok a munkaerőpiacon inaktívként vagy munkanélküliként (lásd 1. ábra) jelen lévőket érintik leginkább. Ezeknek a hátrányoknak a megjelenése és tömegessé válása (vagyis az inaktivitás és a munkanélküliség) számos káros következménnyel járhat mikro- és makrogazdasági szinten egyaránt.

A tartósan fennálló munkaerôpiaci hátrányok gyakran együtt járnak a szegénységgel, a társadalmi feszültséggel és a munkát végzők oldaláról jelentkező igazságtalanságérzettel (Zombori 1997), ami szélsôséges esetben akár a fennálló rendszer elleni tüntetésekhez, lázadásokhoz is vezethet. A makrogazdaságban a kihasználatlan munkaerő-kapacitás miatt kevesebb lesz a hozzáadott érték, ami végső soron mérsékli a gazdasági növekedést. A foglalkoztatásból kiszorulók az államháztartás számára többletkiadást jelentenek, mivel az állam igyekszik a munkaerőpiaci hátrányokat elszenvedők relatív szociális biztonságát különböző juttatásokkal garantálni (Barr 2009).

A munkaerôpiaci hátrányokkal gyakran együtt járó elszegényedés következményeként a háztartások szintjén nem anyagi természetű problémák is előfordulhatnak. Megváltozhat a családfenntartó pozíció, ami konfliktusokkal, a családon belüli szerepek és a kommunikáció átalakulásával, a társadalmi kapcsolatok meglazulásával járhat. A munkanélküliség hatására megváltozhat az egyén önmagáról alkotott képe is, morálisan és mentálisan is nehéz helyzetbe kerülhet. A tartósan fennálló munkanélküliség

Területi Statisztika, 2016, 56(4): 438-454; DOI: 10.15196/TS560405 
különböző egészségügyi problémák (mint a szív- és érrendszeri megbetegedések) okozója is lehet. Munkanélküliség esetén a napi rendszerességú kötelességektől való elszakadás miatt később nehezebb a munka világába újra bekapcsolódni. Ez különösen tartós munkanélküliség esetén jelent problémát (Darók 2006, G. Fekete 2015, Dabasi Halász et al. 2016).

1. ábra

\section{A lakosság munkaerőpiaci összetétele}

Labour market composition of the population

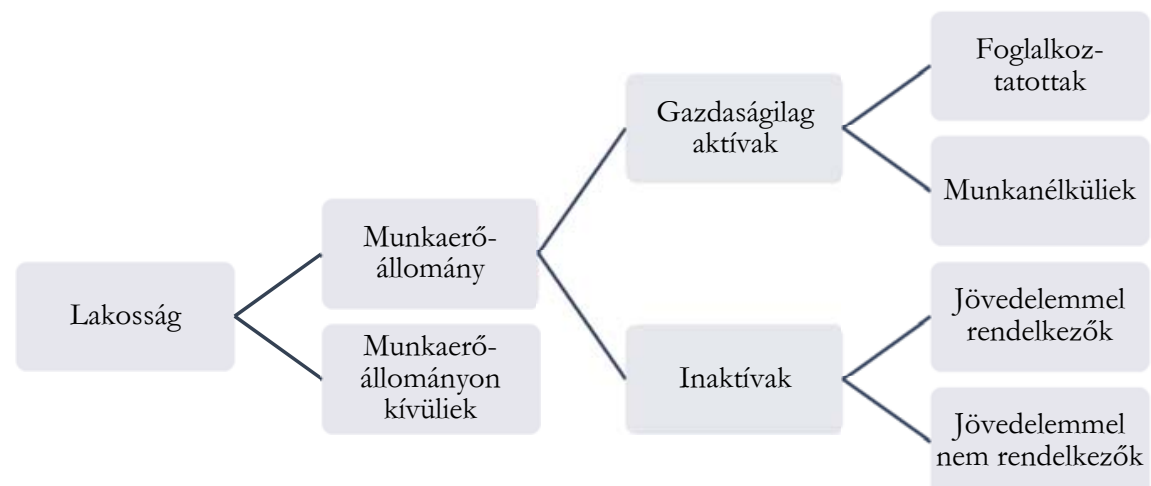

Forrás: Dabasi Halász 2011. 17. old. alapján saját szerkesztés.

\section{Területi hatások a munkaeröpiacon}

A felsorolt érvek megteremtik a munkaerőpiaci hátrányok felszámolását célzó programok és kutatások jogosultsági alapját. A munkanélküliség és az inaktivitás okainak és körülményeinek feltárásakor ugyanakkor nem hagyhatók figyelmen kívül a területi vonatkozások. Egyrészt azért, mert az országos adatok nem nyújtanak információt a munkanélküliség térségi struktúrájáról, viszont a munkanélküliség egyenlótlenségei a kisebb területi egységek között sokszor akkorák, mint az országok között. Másrészt az országos szintű makroökonómiai vizsgálatok (amelyek sokszor arra a következtetésre jutnak, hogy a munkaerôpiac olyan intézményei, mint a bértárgyalások vagy a munkavállalók védelme okozhatnak ugyan országok közötti eltéréseket, de országon belül nem különböznek) a munkanélküliség regionális eltéréseit nem magyarázzák. Végül azért is, mert a munkaerőpiacon a fejlettség és az elmaradottság térben koncentráltan jelenik meg, és ezek kialakulásában a térbeliség sokszor játszik magyarázó szerepet (Lő́csei 2010). E szempontokat felismerve az elmúlt két évtizedben számos tanulmány vizsgálta a munkanélküliség tekintetében fennálló regionális különbségeket (Taylor 1996, Ábrahám-Kertesi 1996, Fazekas 2003, Elhorst 2003, Nemes NagyNémeth 2005, Rios 2014).

A munkanélküliség regionális különbségeinek magyarázatára kétféle elmélet alakult ki. Az egyensúlyi elmélet szerint minden térség a saját egyensúlyi munkanélküli- 
ségi rátája felé tart, amelyet a regionális kereslet, kínálat, valamint az intézmények határoznak meg. Egy adott térség magas munkanélküliségi rátáját ellensúlyozzák olyan pozitív tényezők, mint a kedvező klimatikus viszonyok vagy a vonzó társadalmi és intézményi környezet, amelyek meggátolják az elvándorlást (Marston 1985). A helyi rátákat a helyi viszonyok is befolyásolják, és mivel ezek eltérőek, így a munkanélküliségi ráták is eltérōek a térben.

Az egyensúlytalanság elmélete szerint minden térség a saját versenyképes egyensúlyi munkanélküliségi rátája felé tart, és a munkanélküliségi ráták a területi egységek között kiegyenlítődnek (Blanchard-Katz 1992). Rövid távon a regionális különbségeket a munkaerôpiac olyan merevségei okozhatják, mint a korlátozott mobilitás vagy az aszimmetrikus sokkokhoz (például az elégtelen munkaerô-kereslet) való lassú alkalmazkodási folyamatok. Az igazodási folyamat lehet lassú és gyors is. Ettől függően a munkanélküliség különbségei akár hosszabb időn keresztül is fennmaradhatnak. Hosszú távon azonban a különbségek a migrációval és az egyéb tényezôk mobilitásával összefüggésben eltűnnek. Ez a neoklasszikus elméletből származik, amely szerint a növekvő gazdasági integrációval és a termelési tényezők szabad áramlását nehezítő akadályok felszámolásával a munkanélküliségi ráták konvergálnak, vagyis a regionális különbségek eltűnnek (Rios 2014, 2. old.).

Ez utóbbi elmélet gyengéje, hogy nem határozza meg pontosan azt, mekkora is az a hosszú táv, amikor az egyensúlytalanság megszűnik, és a regionális munkanélküliségi ráták különbségei eltûnnek, valamint az elmélet elnevezése is félrevezető lehet, hiszen hosszú távon éppen egyensúlyt és nem egyensúlytanságot állapít meg.

\section{A munkanélküliséget általánosan befolyásoló tényezők}

A munkaerôpiaci folyamatok alakulását számos gazdasági és nem gazdasági tényező befolyásolhatja. A munkaerôpiacot elemző kutatások eredményei alapján a munkaerőpiacra és azon belül a munkanélküliségre ható tényezőket a következők szerint összegezhetjük.

A gazdasági teljesitmény munkanélküliségre gyakorolt jelentős hatása a legtöbb elemző körében vitathatatlan. A gazdasági növekedés mérsékli, míg a gazdasági viszszaesés növeli a munkanélküliség mértékét (Tuharska 1998, McConnell-Brue 1999, Noor et al. 2007, Subhan- Hayat 2010, Samuelson-Nordhaus 2009, Martinkus et al. 2009, Vojtovich 2013). Közép- és Kelet-Európában azonban a gazdasági teljesítmény fent említett munkaerőpiaci hatása csak minimális mértékben jelentkezik (AlbertHahnel 1991, Stiglitz 2003, Altvater-Mahnkopf 2007, Skidelsky 2008, Stiglitz 2008, Ressler 2008).

A beruháąások, illetve azon belül a külföldimúködőtőke-beáramlás (FDI) hatása is számos elemzés során bizonyult szignifikánsnak (Shapiro-Stiglitz 1984, Belot-van Ours 2001, Valadkhani 2003, Sileika-Andriusaitiene 2006, Bucek et al. 2008, Ashipala-Eita 2010). További fontos szerepet játszó gazdasági tényező a reálkamatláb (Blanchard-Wolfers 1999, Ball 1999, Nickell et al. 2001, Baccaro-Rei 2007), mely a

Területi Statisztika, 2016, 56(4): 438-454; DOI: 10.15196/TS560405 
legtöbb kutatás szerint pozitív kapcsolatban áll a munkanélküliségi rátával (Ball 1999, Nickell et al. 2001, Baccaro-Rei 2007). A külkereskedelmi cserearány javulása munkanélküliséget csökkentő tényezőnek bizonyul (Baccaro-Rei 2007).

További fontos tényezók lehetnek az olyan egyensúlytalansági tényezóke, mint a foglalkoztatás bővülése, a kibocsátási rés vagy az infláció (Partridge-Rickman 1997, Valadkhani 2003, Ashipala-Eita 2010, Rios 2014). A kibocsátási rés a tényleges és a potenciális (trend szerinti) gazdasági teljesítmény különbsége. A munkanélküliség és az infláció közötti fordított arányosság a Philips-görbe érvényességét támasztja alá (Ashipala-Eita 2010, Bakare 2011). Ezen egyensúlytalansági tényezők a munkanélküliség regionális egyenlőtlenségeit is magyarázzák, hiszen ha egy adott régióban a foglalkoztatás vagy a gazdaság teljesítménye gyorsabban nő az átlagosnál, akkor az adott régió munkanélkülisége az átlaghoz képest csökkenni fog.

A piaci egyensúlyi tényerốk (szektorális diverzifikáció, szektorális aktivitás és foglalkoztatás) szintén befolyásolhatják a munkanélküliséget. Egyrészt minél nagyobb mértékben specializálódott ugyanis a gazdaság, annál kevésbé képes a foglalkoztatás csökkenéséhez alkalmazkodni (Simon 1988). Másrészt viszont a specializálódottabb régiókban múködő vállalkozások termelékenyebbek (Partridge-Rickman 1997, Rios 2014).

A foglalkoztatás súrüsége azért fontos szempont a munkanélküliség szempontjából, mert ahol magasabb a foglalkoztatás sűrűsége, ott egyrészt nagyobb valószínűséggel találkozik a munkaerő-kereslet és -kínálat, másrészt viszont a munkát keresők több időt tölthetnek az üres álláshelyekre vonatkozó információk gyújtésével, ami időigényesebbé teheti az álláskeresést és a megfelelő munkavállaló megtalálását (PartridgeRickman 1997, Rios 2014).

A munkaerőpiaci viszonyokat befolyásolják még a népesség demográfiai összetétele és annak változásai, valamint a munkaeró-kinálat jellemzői (Bakare 2011). Ezen belül meghatározó jelentőségúek a következők:

- Természetes szaporodás: amennyiben ennek mértéke meghaladja a foglalkoztatás bővülésének mértékét, és hosszabb távon a munkanélküliség növekedését eredményezi (Groenewold 1997). Refiq és szerzőtársai (2010) a pakisztáni munkaerôpiac elemzése során szintén arra a következtetésre jutottak, hogy a népességszám emelkedése megemeli a munkanélküliek számát.

- Az időskorú népesség aránya (Rios 2014).

- A népesség átlagos iskolai végzettsége (Ábrahám-Kertesi 1996, Vojtovich 2013, Rios 2014).

- A nők gazdasági aktivitása (Mahmood et al. 2014, Rios 2014).

- A nettó migrációs ráta (Vojtovich 2013, Rios 2014).

- A roma népesség aránya (Ábrahám-Kertesi 1996).

A munkaerópiac intézményei (mint a különböző munkanélküli-ellátások, a foglalkoztatottakat védő törvények, a szakszervezeti tagok aránya, a tax wedge vagy a központi bank függetlenségének mértéke) szintén hatással vannak a munkanélküliség mértékére (Partridge-Rickman 1997, Baccaro-Rei 2007, Rios 2014).

Területi Statisztika, 2016, 56(4): 438-454; DOI: 10.15196/TS560405 
Magyarországon a munkanélküliség regionális különbségeinek okait - a munkanélküliség megjelenését követően - az 1990-es évek elején kezdték kutatni. Az 1990-es évek első felében a munkanélküliség regionális eltéréseit részben az etnikai hovatartozás (a roma népesség aránya), részben az iskolázottsági szint befolyásolta (Ábrahám-Kertesi 1996). Később a munkanélküliség mértékében fennálló kelet-nyugati megosztottságot a külföldi múködő tôke egyenlőtlen regionális eloszlásával hozták összefüggésbe (Fazekas 2003). A munkanélküliség regionális különbségeinek fennállásában a migráció alacsony szintje is szerepet játszik (Nemes Nagy-Németh 2005).

\section{Munkanélküliség Észak-Magyarországon}

A régió megyéiben a munkanélküliség az országos trendeket követi (lásd 2. ábra). A munkanélküliség 2009-2010-ben érte el a legmagasabb értékeit, amit rövid stagnálás követett. A munkanélküliség 2012-től kezdett csökkenni, ami egyrészt az ingázási típusú külföldi munkavállalás bővülésére (elsősorban Ausztria és Németország felé), másrészt a közfoglalkoztatás jelentős növekedésére, harmadrészt pedig a versenyszférában megvalósult munkahelyteremtésekre vezethető vissza. A foglalkoztatás növekedése a munkaerő-kínálat bővülése mellett következett be, ami a nyugdíjkorhatár emelésével, a tankötelezettségi korhatár leszállításával, a gyed extra bevezetésével és a közfoglalkoztatás kiterjesztésével függött össze (Bakó-Lakatos 2015).

\section{Az Észak-Magyarország megyéiben nyilvántartott álláskeresők aránya és relatív szórása a munkavállalási korú népesség százalékában}

Proportion and relative standard deviation of job seekers registered in the counties of Northern Hungary as a percentage of the working age population

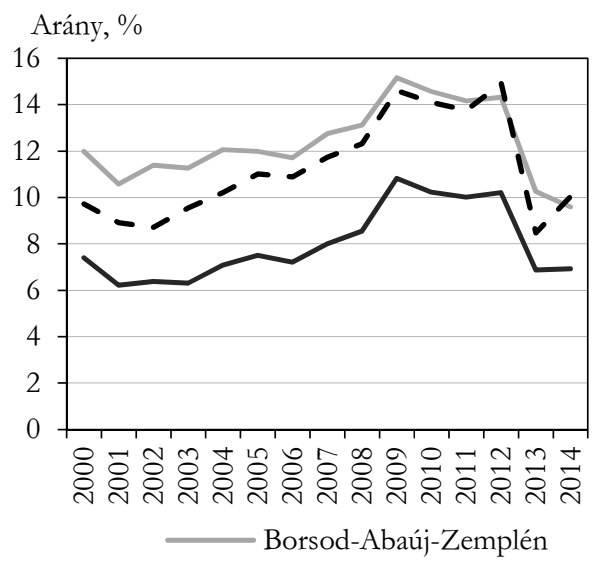

Relatív szórás, \%

Forrás: Dabasi Halász et al. 2016., 56. old.

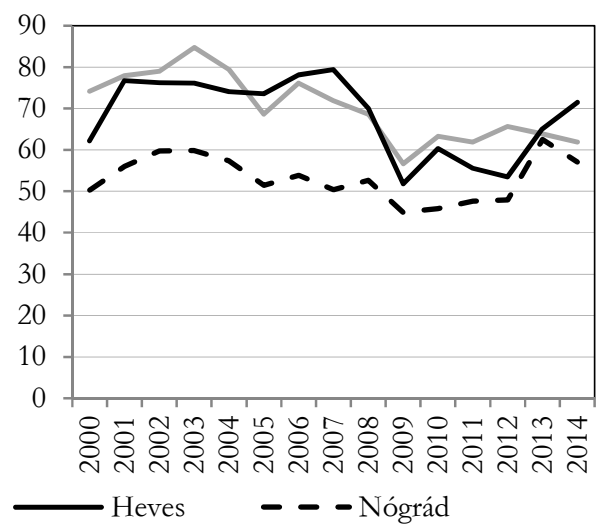

Területi Statisztika, 2016, 56(4): 438-454; DOI: 10.15196/TS560405 


\section{Kutatási kérdések, módszertan}

Tanulmányunkban arra keresünk választ, hogy 2014-ben hogyan alakult az álláskeresők arányának területi autokorreláltsága. A szubnacionális területi egységek között többnyire erôs a kölcsönhatás, ami egyrészt a településeken átívelő termelési folyamatokkal, másrészt a termelési tényezők települések közötti áramlásával függ össze (Kocziszky 2013). Feltételezzük, hogy mivel a munkaerőpiacon az elmúlt években fellendülés (a munkanélküliség csökkenése, a foglalkoztatás bővülése) tapasztalható, a vizsgált régióban cold spotok igen, viszont hot spotok nem találhatóak. Előfordulnak még mindig magas munkanélküliséggel sújtott települések, de azok nem alkotnak egy összefüggő magas-magas klasztert, csupán a magas-alacsony kategóriába tartoznak.

A munkanélküliek arányát a KSH 2014. évi területi statisztikai adataiból határoztuk meg Észak-Magyarország településeire. A hipotézis teszteléséhez a Local Moran I mutatót használtuk, ami azt mutatja meg, hogy adott területi egység mennyiben hasonlít vagy különbözik a környezô területi egységektől a vizsgált jellemző tekintetében (Tóth 2003). A mutató definíciója:

$$
I_{i}=\frac{\left(Z_{i}-\bar{Z}\right)}{S_{Z}^{2}} * \sum_{j=1}^{N}\left[W_{i j} *\left(Z_{j}-\bar{Z}\right)\right]
$$

ahol $Z_{i}$ az i-edik területi egységhez tartozó érték, $Z_{j}$ valamennyi, az i-n kívüli területi egység értéke, $\bar{Z}$ a területi egységek átlaga, $S_{Z}^{2}$ a területi egységekhez tartozó értékek szórása, $W_{\text {ij }}$ pedig az i és a j területi egységek közötti súly (Getis-Ord 1996).

A Local Moran I értékeit a GeoDa-szoftver segítségével számítottuk ki. A súlymátrix meghatározásához a szomszédságot az öt legközelebbi szomszéd településként definiáltuk. Mivel a vizsgált régióban 610 település található, az esetszám ezt lehetôvé teszi.

E tanulmány másik kutatási kérdése, hogy Észak-Magyarországon mely tényezők befolyásolják a munkanélküliség alakulását, különös tekintettel a gazdasági teljesítmény munkaerőpiaci hatásának feltárására. Míg a legtöbb országban szignifikáns a hatás, addig Közép- és Kelet-Európában minimális a gazdasági teljesítmény munkanélküliséget csökkentő hatása. Az előző fejezetben felsorolt kutatások eredményeit felhasználva a következő, a munkanélküliséget potenciálisan befolyásoló változókat vettük figyelembe:

- egy főre jutó jövedelem mint a gazdasági teljesítmény kistérségi/járási szintű mérôszáma,

- a szomszédos területek átlagos egy főre jutó jövedelme,

- beruházások: mivel a beruházások értéke a KSH adatbázisában megyei szinten szerepel, azokat arányosan osztottuk fel a kistérségek között, melyet három arány átlagaként határoztunk meg (a népességarányos, a városinépesség-arányos és a vállalkozásarányos beruházás értékeket átlagolva),

- a foglalkoztatás változása,

- kibocsátási rés, melyet - lévén, hogy kistérségi/járási szinten a gazdasági teljesítmény az egy főre jutó jövedelemmel mérhető - a tényleges és a potenciális 
(trend szerinti) egy főre jutó jövedelem különbségeként határoztunk meg, a következő módon számítva: tényleges jövedelem - potenciális jövedelem potenciális jövedelem

A potenciális (trend szerinti) jövedelem meghatározásához az 1992 és a 2004 közötti időszak kistérségi egy főre jutó jövedelemadatait vettük alapul, és ezekre az adatsorokra illeszkedő OLS regressziós egyenes 2011. évhez tartozó értékei adták a potenciális jövedelmet, a következő változók felhasználásával:

- az iparban foglalkoztatottak aránya,

- a mezőgazdaságban foglalkoztatottak aránya,

- a foglalkoztatás sűrűsége,

- a 60 éves és idősebb népesség aránya,

- a gazdaságilag aktív nők aránya,

- átlagos iskolai végzettség,

- vándorlási különbözet,

- a roma népesség aránya.

A szomszédos területek átlagos egy fơre jutó jövedelménél azon kistérségek adatait vettük figyelembe, melyeknek a vizsgált kistérséggel közös határvonaluk van. Ezt a változót a szomszédsági hatások figyelembevétele érdekében vizsgáltuk, mivel korábbi kutatások kimutatták, hogy a szomszédsági hatások jelentős szerepet játszanak a munkanélküliség alakulásában (Lőcsei 2010). A foglalkoztatás növekedését a foglalkoztatottak számának 2001-rôl 2011-re bekövetkező százalékos változásával mértük. A gazdaságilag aktív nők arányát az összes aktívhoz viszonyítva határoztuk meg. Az átlagos iskolai végzettséget az elvégzett átlagos osztályszámmal mértük. Ennek értéke 0 azoknál, akik az általános iskola első évfolyamát sem végezték el; 4 azoknál, akik az általános iskola 1-7. osztályát végezték el, 8 azoknál, akik az általános iskola 8 . évfolyamát végezték el; 11 azoknál, akik középfokú iskolát végeztek érettségi nélkül, szakmai oklevéllel; 12 azoknál, akik érettségiztek; és 16 azoknál, akik egyetemet, főiskolát végeztek. A foglalkoztatás sűrűségét az egy $\mathrm{km}^{2}$-re jutó foglalkoztatottak számával mértük. A vizsgált változók értékeit kistérségi bontásban határoztuk meg a 2011. évi népszámlálási adatokat felhasználva. ${ }^{1} \mathrm{Az}$ intézmények változóit, a kamatlábat, a külkereskedelmi cserearányt, az inflációt nem vontuk be az elemzésbe, mivel ezek a vizsgált régió minden területegységére nézve azonosak. A demográfiai változók között vizsgáltuk a roma népesség arányát, mivel ennek Magyarországon jelentős hatása volt a munkaerőpiaci folyamatokra (Ábrahám-Kertesi 1996, Dabasi Halász 2011).

A felsorolt változók közül többváltozós OLS regressziószámítás segítségével határoztuk meg azon változók körét, melyek szignifikánsan befolyásolják a munkanélküliségi ráta, mint függő változó alakulását. Ehhez 5\%-os szignifikanciaszintet és SPSS-programot használtunk.

${ }^{1}$ 2011-ben a megyék járások helyett kistérségekre voltak tagolva, így ezeket használtuk az elemzés során.

Területi Statisztika, 2016, 56(4): 438-454; DOI: 10.15196/TS560405 


\section{Területi hatások az észak-magyarországi munkanélküliség alakulásában}

A gazdasági világválság kirobbanását követő években végzett autokorrelációs vizsgálatok kimutatták, hogy 2008 szeptembere és 2010 augusztusa között a magyarországi kistérségek vonatkozásában a nyilvántartott álláskeresők klasztereinek térbeli elrendeződése nem sokat változott. Észak-Magyarország keleti fele a lokális Moran I értékek alapján a magas-magas kategóriába tartozott, vagyis mind az adott kistérségben, mind azok szomszédos kistérségeiben átlagosan magas volt az álláskeresők aránya. Egyetlen kivétel a Tiszaújvárosi kistérség, ahol a munkanélküliek alacsony aránya a szomszédos kistérségek magas munkanélküliségi rátájával párosult. A régió nyugati felében a Salgótarjáni, valamint 2010-ben azon kívül még a Pétervásárai kistérség tartozott a magas-magas kategóriába. E kistérségeken kívül a régió nyugati felében nem fordult eló szignifikáns autokorreláció (Lőcsei 2010).

A területi autokorrelációt vizsgálva megállapítható, hogy a települések több mint háromnegyedében a munkanélküliek arányát tekintve nincs szignifikáns autokorreláció (3. és 4. ábra). Hot spotok (vagyis ahol a magas munkanélküliséggel sújtott települést magas munkanélküliségú települések veszik körül) találhatóak az Edelényi, Encsi és Szikszói kistérségekben, a Szerencsi kistérség déli részén (Taktaszada, Prügy, Taktakenéz), a Szécsényi és Salgótarjáni kistérségek északi részén, valamint az Ózdi kistérség nyugati részén. Cold spotok (ahol elsősorban alacsony munkanélküliséggel jellemezhető települések tömörülnek) fordulnak elő Tiszaújváros környékén, a Szirmabesenyő-Arnót-Onga- Sajóvámos-Sajóselye által meghatározott területen, Aggtelek és Jósvafő környékén, Borsod-Abaúj-Zemplén megye déli részén (Mezőkövesd, Mezőkeresztes, Szentistván, Tiszabábolna, Négyes), a Füzesabonyi kistérség keleti részén, Miskolctól észak-nyugatra, Egerben és a környező településeken, valamint a Hatvani és a Gyöngyösi kistérség nyugati részén.

Több helyen az egységesen magas munkanélküliségú tömbből néhány település az alacsony értékével tűnt ki. Ilyenek például: Kisköre, Hevesvezekény, Bükkszék, Révleányvár, Csobaj, Hidvégardó, Viszló, Szemere, Hernádszurdok, Garadna, Irota, Gagybátor, Abaújlak, Alsógagy, Ludányhalászi, Szécsény, Kisbárkány. Más települések a környező alacsony értékek közül magas értékeikkel emelkedtek ki: Egerbakta, Kerecsend, Poroszló, Halmajugra, Bükkaranyos, Sály, Imola, Zádorfalva, Martonyi, Rakacaszend, Legénd, Becske.

Mivel a munkaerőpiaci hátrányok leginkább a tartós munkanélküliség esetén jelentkeznek, érdemes a tartósan munkanélküliek, vagyis az egy éve vagy annál régebben állás nélkül lévők arányában fellelhető szomszédsági hatásokat külön is megvizsgálni. A Local Moran I értékek ez esetben is a régió délnyugati részén jeleznek elsősorban cold spotokat, míg a hot spotok döntő többsége a régió északi részén terül el (5. és 6. ábra). 
A munkanélküliek észak-magyarországi arányának

3. ábra Local Moran I értéke, 2014

Local Moran I of the unemployment rate in Northern Hungary, 2014

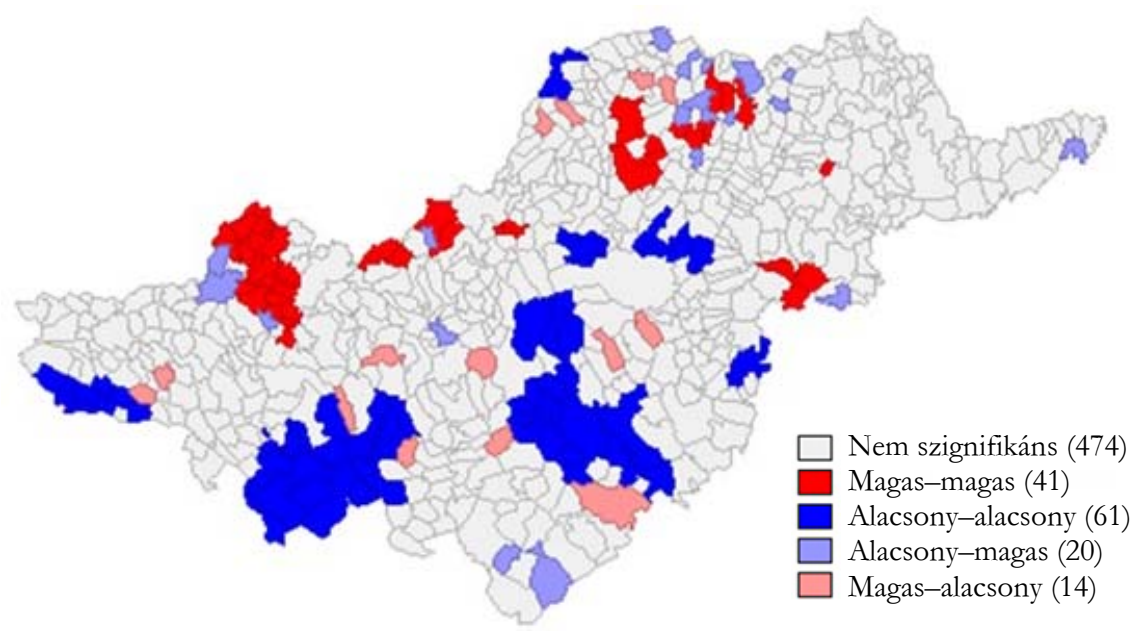

A munkanélküliek észak-magyarországi arányának

4. ábra Local Moran I szignifikanciája, 2014

Significance of Local Moran I of the unemployment rate in Northern Hungary, 2014

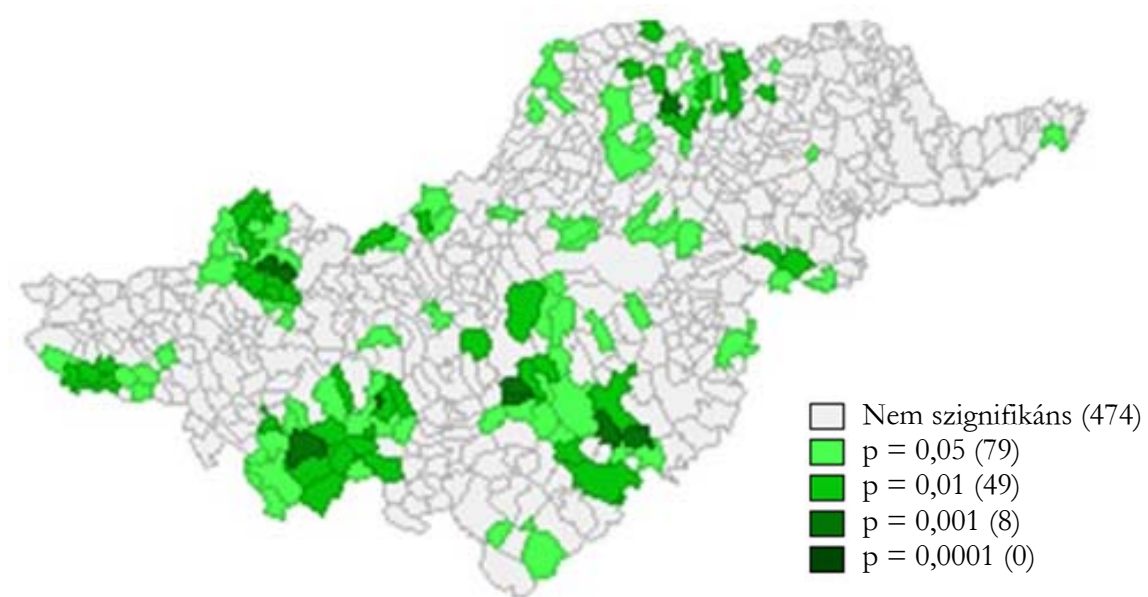

Területi Statisztika, 2016, 56(4): 438-454; DOI: 10.15196/TS560405 
A tartósan munkanélküliek észak-magyarországi arányának

5. ábra Local Moran I értéke, 2014

Local Moran I of the long-term unemployment rate in Northern Hungary, 2014

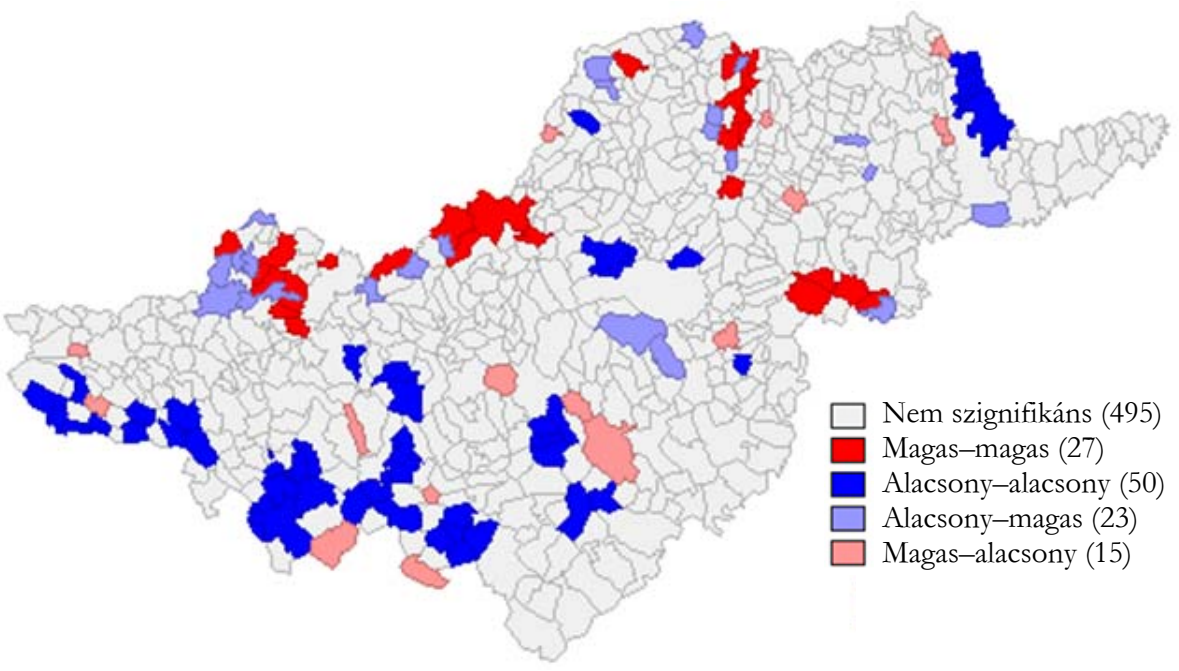

A tartósan munkanélküliek észak-magyarországi arányának

6. ábra Local Moran I szignifikanciája, 2014

Significance of Local Moran I of the long-term unemployment rate in Northern Hungary, 2014



Területi Statisztika, 2016, 56(4): 438-454; DOI: 10.15196/TS560405 
Hot spot található a Szerencsi kistérség déli részén, a Szikszói és az Encsi kistérség nyugati részén, Ózdon és környékén, az Edelény melletti Szinben, valamint a Salgótarjáni kistérségben. A cold spotok Sátoraljaújhelyen és környékén, Miskolctól északra, Heves megye déli részén, Egertől délre és Nógrád megye délnyugati részén fordulnak elő. Néhány településen a környező magas munkanélküliség ellenére alacsony értékeket találtunk. Ilyenek például: Nógrád, Berkenye, Szendehely, Ôsagárd, Rétság, Nézsa, Legénd, Bercel, Galgaguta, Vanyarc, Dorogháza, Kisgyőr, Harsány, Csobaj, Györgytarló, Sima, Arka, Irota, Szakács, Hidvégardó, Jósvafő, Teresztenye. Máshol adott település magas értéke a szomszéd települések alacsony értékével párosul: Horpács, Felsőpetény, Csány, Tarnaörs, Ludas, Gyöngyösoroszi, Egerbakta, Gömörszőlős, Ónod, Felsődobsza, Füzérkajata, Makkoshotyka, Szomolya, Mezőkövesd. Ez utóbbi település a munkanélküliek arányának vizsgálatánál cold spotként jelent meg, vagyis míg a munkanélküliség az adott településen és a környezetében is alacsony, addig a tartósan munkanélküliek aránya - a szomszédos alacsony értékektől eltérően - Mezőkövesden magas.

Összességében megállapítható, hogy a régió déli részén számos cold spot található, ami a munkaerôpiaci fellendülés jele. Ugyanakkor hot spotok is fellelhetőek, elsősorban a régió keleti felén, különösen Borsod-Abaúj-Zemplén megye és Nógrád megye északi részein. A kiinduló hipotézisünk tehát nem fogadható el. A hot spotok jelenléte azt jelzi, hogy a gazdasági világválság utáni fellendülés és a közmunkaprogramok felfutása ellenére a régiónak még vannak marginalizálódott, periférikus térségei.

\section{A munkanélküliséget befolyásoló tényezök regressziós elemzése}

A felsorolt 13 magyarázó változó bevonásával elvégzett regressziószámítás során a szignifikánsnak bizonyult magyarázó változók (egy fơre jutó jövedelem, az iparban foglalkoztatottak aránya, a mezőgazdaságban foglalkoztatottak aránya, a 60 éves és idősebb népesség aránya, a gazdaságilag aktív nők aránya, átlagos iskolai végzettség) közül az átlagos iskolai végzettség VIF értéke nagyon magas (1. táblázat 1. lépése), ezért az elemzést e változó kihagyásával is elvégeztük. Ez esetben (1. táblázat 2. lépése) a szignifikáns magyarázó változók VIF értékei elfogadhatóak, és a regressziós elemzés többi feltétele is teljesült.

Területi Statisztika, 2016, 56(4): 438-454; DOI: 10.15196/TS560405 
A regressziószámítás eredménye

1. táblázat

Result of the regression analysis

\begin{tabular}{|c|c|c|c|c|}
\hline \multirow{2}{*}{ Változó } & \multicolumn{2}{|c|}{ 1. lépés } & \multicolumn{2}{|c|}{ 2. lépés } \\
\hline & $\begin{array}{l}\text { koefficiens } \\
\text { (t érték) }\end{array}$ & VIF & $\begin{array}{l}\text { koefficiens } \\
\text { (t érték) }\end{array}$ & VIF \\
\hline Konstans & $\begin{array}{r}143,295 \\
(5,687)\end{array}$ & & $\begin{array}{l}75,75 \\
(8,341)\end{array}$ & \\
\hline Egy főre jutó jövedelem & $\begin{array}{l}-0,022 \\
(-1,919)\end{array}$ & 7,566 & $\begin{array}{l}-0,045 \\
(-9,404)\end{array}$ & 1,032 \\
\hline $\begin{array}{l}\text { A szomszédos kistérségek } \\
\text { átlagos egy főre jutó } \\
\text { jövedelme }\end{array}$ & - & - & - & - \\
\hline Beruházás & - & - & - & - \\
\hline A foglalkoztatás változása & - & - & - & - \\
\hline Kibocsátási rés & - & - & - & - \\
\hline $\begin{array}{l}\text { Az iparban foglalkoztatot } \\
\text { tak aránya }\end{array}$ & $\begin{array}{l}-0,617 \\
(-4,038)\end{array}$ & 1,769 & $\begin{array}{l}-0,348 \\
(-2,543)\end{array}$ & 1,081 \\
\hline $\begin{array}{l}\text { A mezőgazdaságban } \\
\text { foglalkoztatottak aránya }\end{array}$ & $\begin{array}{r}-1,049 \\
(-2,059)\end{array}$ & 1,554 & - & - \\
\hline A foglalkoztatás sűrűsége & - & - & - & - \\
\hline $\begin{array}{l}\text { A } 60 \text { éves és idősebb } \\
\text { népesség aránya }\end{array}$ & $\begin{array}{l}-0,723 \\
(-2,537)\end{array}$ & 1,767 & $\begin{array}{l}-1,148 \\
(-4,243)\end{array}$ & 1,213 \\
\hline $\begin{array}{l}\text { A gazdaságilag aktív nők } \\
\text { aránya }\end{array}$ & $\begin{array}{c}0,180 \\
(2,373)\end{array}$ & 1,131 & $\begin{array}{c}0,198 \\
(2,279)\end{array}$ & 1,120 \\
\hline Átlagos iskolai végzettség & $\begin{array}{c}-8,267 \\
(-2,652)\end{array}$ & 10,007 & - & - \\
\hline $\begin{array}{l}\text { Belföldi vándorlási } \\
\text { különbözet }\end{array}$ & - & - & - & - \\
\hline A roma népesség aránya & - & - & - & - \\
\hline $\begin{array}{l}\mathrm{F} \text { (szignifikancia) } \\
\mathrm{R}^{2}\end{array}$ & $\begin{array}{r}34,058 \\
0,\end{array}$ & 00) & $\begin{array}{r}37,22 \\
0\end{array}$ & \\
\hline
\end{tabular}

A gazdaságilag aktív nők arányának emelkedése növeli a munkanélküliek arányát, míg az egy főre jutó jövedelem, az iparban foglalkoztatottak arányának és a 60 évesnél idősebb népesség arányának emelkedése csökkenti a munkanélküliséget.

Az, hogy a gazdaságilag aktív nők arányának emelkedése növeli a munkanélküliek arányát, arra utal, hogy azok közül az inaktív nők közül, akik úgy döntenek, hogy munkát vállalnak és megjelennek a munkaerőpiacon aktív munkakeresőként, sokan munkanélküliek maradnak. Országos szinten is igaz az, hogy a gazdaságilag aktív nők nagyobb valószínűséggel válnak munkanélkülivé, mint a férfiak, vagyis a gazdaságilag aktív nők között nagyobb arányú a munkanélküliség, mint a gazdaságilag aktív férfiak között. A nők jellemzően alacsonyabb munkanélküliségi rátája azzal magyarázható, 
hogy a nem foglalkoztatott nők inkább inaktívvá válnak a munkanélküliség helyett, és ezzel nem emelik a munkanélküliségi ráta értékeit.

Az egy főre jutó jövedelmek emelkedése növeli a munkahelykínálatot, vagyis újabb és újabb munkavállalók áramlanak be a munkaerőpiacra. A jövedelememelkedés kistérségi szinten a gazdasági növekedés indikátora. Így megállapítható, hogy a gazdasági teljesítmény növelése szignifikánsan csökkenti a munkanélküliséget, vagyis a gazdasági növekedés munkaerőpiaci hatása - számos Kelet- és Közép-Európában végzett kutatással szemben - nem csupán minimális mértékben csökkenti a munkanélküliek arányát.

A 60 évesnél idősebb népesség arányának növekedésével csökken a munkanélküliség, ami azt jelzi, hogy a munkavállalási korból kikerülők egy része korábban munkanélküliként volt nyilvántartva. Azzal, hogy ők kikerülnek a munkaerô-állományból, javítják a munkanélküli adatokat.

A szektorális foglalkoztatás tekintetében megállapítható, hogy az ipari foglalkoztatás bővülése képes szignifikánsan csökkenteni a munkanélküliséget, a mezőgazdasági foglalkoztatás bővülésének azonban nincs ilyen hatása.

\section{Összegzés}

A munkanélküliséget befolyásoló tényezôk közül gazdasági (gazdasági teljesítmény, az iparban foglalkoztatottak aránya) és a demográfiai tényezők (a 60 éves és idősebb népesség aránya, a gazdaságilag aktív nők aránya) bizonyultak szignifikánsnak. ÉszakMagyarországon az egyensúlytalansági tényezők nem befolyásolják szignifikánsan a munkaerőpiaci hátrányok alakulását. A munkanélküliség mérséklését célzó stratégiáknak tehát a gazdasági teljesítmény növelésére, az ipari szektorbeli létszámbővítésre, valamint a nem és a korstruktúra megfelelő alakulására, továbbá a gazdaságilag aktívak nem és korösszetételének kedvező alakulására kell koncentrálnia. A demográfiai tényezők jellemzően csak hosszabb távon és időbeni késleltetéssel hatnak a munkaerőpiacra.

A roma népesség arányának hatása annak ellenére sem bizonyult szignifikánsnak, hogy a foglalkoztatás visszaesése az 1980-as népszámlálás óta sokkal jelentősebb mértékű a roma többséggel rendelkező településeken (Pásztor-Pénzes 2013).

Kiemelendő, hogy a gazdasági teljesítmény növelése és az ipari foglalkoztatás bővülése mérsékli a munkaerőpiaci hátrányokat, így az említett célok mihamarabbi elérése számos más szempont mellett munkaerőpiaci szempontból is kívánatos. A vidék újraiparosítása ugyanakkor vitatott stratégia, ugyanis egyetlen ágazat sem tudja felszívni az alacsony képzettségű, korábban döntően betanított munkát végző és a válság hatására munkanélkülivé vált fizikai dolgozók tömegét (Barta 2009).

A munkanélküliséget befolyásoló tényezők vizsgálatánál az OLS regressziószámítás módszertana megkívánta, hogy a multikollinearitás problémája miatt az iskolai végzettség változót az elemzésből eltávolítsuk. Fontos azonban megjegyezni, hogy ez nem jelenti a kizárt változó elhanyagolhatóságát a munkanélküliség szempontjából. Éppen ellenkezőleg, a munkaerôpiaccal foglalkozó kutatások egybehangzóan állítják, hogy egy térség felemelkedése elképzelhetetlen az átlagos képzettségi

Területi Statisztika, 2016, 56(4): 438-454; DOI: 10.15196/TS560405 
szint javítása nélkül. A képzettség és a munkanélküliség kapcsolatának vizsgálata Észak-Magyarország régióban ezért további kutatások tárgya lehet.

A területi hatások vizsgálata rávilágít arra, hogy a régió nagy részén a szomszédsági hatások nem szignifikánsak a munkanélküliek arányát tekintve. A régió déli részén azonban található néhány cold spot, ahol valószínúleg a válság utáni fellendülésből és a közmunkaprogram felfutásából tudtak profitálni. A régió északi részén ezzel szemben több marginalizálódott térség is található. G. Fekete (2015) szerint ezek a lemaradó térségek külső szellemi, információs és pénzügyi segítséggel olyan, társadalmi erőforrások bevonását feltételező társadalmi innovációk alkalmazásával javíthatnának a munkaerőpiaci helyzetükön, melyek a munka fogalmának kiterjesztésén alapulnak (mint az önfoglalkoztatóvá válás inkubálása vagy a szociális farm).

A kutatás további lehetséges iránya egyrészt az inaktivitás vizsgálata, ami azért lényeges és releváns, mert a magyarországi munkaerőpiac egyik nagy problémája az inaktívak magas aránya, ami a munkanélküliségi ráta értékeiben nem tükröződik. Így, amennyiben kizárólag a munkanélküliségre koncentrálunk, a munkaerôpiac egyik problémája rejtve marad.

Továbbá a kutatás adatbázisának kibővitése is szükséges a jövőben, a következtetések megbízhatóságának növelése érdekében. Egyrészt a munkanélküliséget befolyásoló tényezőket több évre vonatkozóan lehetne vizsgálni, másrészt nem kistérségi/járási szinten, hanem településsoros adatokkal.

\section{IRODALOM}

ÁBRAHÁM, Á.-KERTESI, G. (1996): A munkanélküliség regionális egyenlőtlenségei Magyarországon 1990 és 1995 között Közgądasági Sremle 43 (7-8): 653-681.

AshipaLA, J. M.-EITA, J. H. (2010): Determinants of Unemployment in Namibia International Journal of Business and Management 5 (10): 92-104.

BACCARO, L.-REI, D. (2007): Institutional determinants of unemployment in OECD countries: does the deregulatory view hold water? Institutional Organization 61 (3): 527-569.

BAKARE, A. S (2011): The determinants of urban unemployment crisis in Nigeria: an econometric analysis Journal of Emerging Trends in Economics and Management Sciences 2 (3): 184-192.

BAKÓ, T.-LAKATOS, J. (2015): A magyarországi munkaerőpiac 2014-ben In: FAZEKAS, K.VARGA, J. (szerk): Munkaerópiaci tïkör 2014 pp. 19-35., MTA Közgazdaság- és Regionális Tudományi Kutatóközpont Közgazdaságtudományi Intézet, Budapest.

BALL, L. (1999): Aggregate Demand and Long-Run Unemployment Brookings Papers on Economic Activity 2: 189-251.

BARR, N. (2009): A jóléti állam gazdaságtana Akadémiai Kiadó, Budapest.

BARTA, GY. (2009): Újraiparosodás és uijraiparositás a gazdasági válság elótt és után In: Regionális tudomány és területpolitikai gyakorlat a Kárpát-medencében Jubileumi tudományos ülésszak, 2009. június 25-26., Pécs. 
Belot, M.-VAn Ours, J. C. (2001): Unemployment and labor market institutions: an empirical analysis Journal of Japanese and International Economics 15 (4): 403-418.

Blanchard, O. J.-Katz, L. F. (1992): Regional evolutions. Brookings Papers on Economic Activity, 23 (1): 1-76.

Blanchard, O.-Wolfers, J. (1999) The Role of Shocks and Institutions in the Rise of European Unemployment: The Aggregate Evidence Economic Journal 110: 1-33.

DABASI HALÁSZ, Zs. (szerk.) (2011): Munkaerópiac és foglalkoztatáspolitika Miskolci Egyetem, Gazdaságtudományi Kar. Miskolci Egyetemi Kiadó, Miskolc.

DABASI HALÁSZ, ZS.-LIPTÁK, K.-SIPOSNÉ NÁNDORI, E. (2016): A fenntarthatatlan munkaerópiac, a munkanélküliség lehetséges okai Észak-Magyarországon In: NAGY,Z.-HORVÁTH, K. (szerk.): Jubileumi Tanulmánykötet Tóthné Szita Klára professzor asszony 70. születésnapjára pp. 52-61., Miskolci Egyetem, Miskolc.

ElHORST, J. P. (2003): The mystery of regional unemployment differentials. Theoretical and empirical explanations Journal of Economic Surveys 17 (5): 709-748.

FAZEKAS, K. (2003): A hazai és a külföldi tulajdonú vállalkozások területi koncentrációja Magyarországon In: FAZEKAS, K. (szerk.): Munkaeröpiaci Tükör 2003 pp: 159-173., MTA Közgazdaságtudományi Intézet. Országos Foglalkoztatási Közalapítvány. Budapest.

GETIS, A.-ORD, J. K. (1996): Local spatial statistics: an overview In: LONGLEY, P.-BATTY, M. (szerk.) Spatial Analysis: Modelling in a GIS pp. 261-277., Environment. GeoInformation International, Cambridge.

G. FEKETE, É. (2015): Társadalmi innovációk a helyi foglalkoztatásban In: VERESNÉ SOMOSI, M.-LIPTÁK, K. „Mérleg és Kibivások” IX. Nemzetközi Tudományos Konferencia A Gazdaságtudományi Kar megalapitásának. 25. évfordulója alkalmából Miskolc-Lillafüred.

Groenewold, N. (1997): Does Migration Equalise Regional Unemployment Rates? Evidence from Australia Papers in Regional Science 76 (1): 1-20.

KOCZISZKY, GY. (2013): Térökonometria alkalmazásának lehetőségei a területi kutatásokban Müszaki Földtudományi Közlemények 84 (1): 111-118.

LŐCSEI, H. (2010): A gazdasági világválság hatása a munkanélküliség területi egyenlőtlenségeire In: FAZEKAS, K.-MOLNÁR, GY. (szerk.): Munkaeröpiaci tükör 2010 pp. 126-141., MTA Közgazdaságtudományi Intézet-Országos Foglalkoztatási Közalapítvány. Budapest.

Marston, S. T. (1985): Two Views of the Geographic Distribution of Unemployment The Quarterly Journal of Economics 100 (1): 57-79.

Martinkus, B.-Stoskus, S.-Berzinskiene, D. (2009): Changes of Employment through the Segmentation of Labour Market in the Baltic States Inzinerine EkonomikaEngineering Economics 63 (4): 41-48.

Mcconnell, C. R.-Brue, S. L.-Flynn, S. M. (1999): Economics. Principles, Problems and Policies Irwin McGraw-Hill, New York.

Mahmood, T.-Ali, A.-AKhtar, N.-IQBAL, M.-QAmar, S.-ZAFAR NAZIR, H.-ABBAs, N.SANA, I. (2014): Determinants of unemployment in Pakistan: a statistical study International Journal of Asian Social Science 4 (12): 1163-1175.

Nemes NAgy, J.-NÉmeth, N. (2005): Az átmeneti és az új térszerkezet tagoló tényezői In: FAZEKAS, K. (szerk.): A hely és a fej pp. 75-137., Munkapiac és regionalitás Magyarországon. MTA Közgazdaságtudományi Intézet, Budapest.

Területi Statisztika, 2016, 56(4): 438-454; DOI: 10.15196/TS560405 
Nickell, S.-NunZiata, L.-Ochel, W.-Quintini, G. (2001): The Beveridge Curve, Unemployment and Wages in the OECD CEP Discussion Papers 0502. Centre for Economic Performance, LSE, London.

NoOR, Z. M.-NOR, N. M.-GJANI, J. A. (2007): The relationship between output and unemployment in Malaysia: does Okun's law exist? International Journal of Economics and Management 1 (3): 337-344.

PARTRIDGE, M. D.-RiCKMAN, D. S. (1997): State Unemployment Differentials: Equilibrium Factors vs. Differential Employment Growth Growth and Change 28 (3): 360-379.

PÁsZTOR, I. Z.-PÉNZES, J. (2013): Foglalkoztatási krízis és jövedelmi periferizálódás Északkelet-Magyarországon a roma népesség arányainak tükrében Területi Statisztika 53 (3): 202-224.

RAFIQ, M.-AHMAD, I.-ULLAH, A.-KHAN, Z. (2010): Determinants of unemployment: a case study of Pakistan economy (1998-2008). Abasyn Journal of Social Sciences 3 (1): 17-24.

RIOS, V. (2014): What drives regional unemployment disparities in Euroean regions? A Space-time econometric modeling approach International Conference on Regional Sciences: Financing and the role of the regions and towns in economic recovery, Zaragoza.

SAmuelson, P. A.-Nordhaus, W. D. (2009): Közgazdaságtan Akadémiai Kiadó Zrt., Budapest.

SileikA, A.-Andriusaitiene, D. (2006): Problems of Identifying and Regulating the Structure of the Labour Market in Depressive Lithuanian Regions Journal of Business Economics and Management 7 (4): 223-233.

SHAPIRO, C.- STIGLITZ, J. E. (1984): Equilibrium Unemployment as a Worker Discipline Device The American Economic Review 74 (3): 433-444.

SimON, C. J. (1988): Frictional Unemployment and the role of Industrial Diversity Quartely Journal of Economics 103 (4): 715-728.

SubHan, Q. A.-HAyAT, M. A. (2010): Impact of Price instability on Unemployment and Economic Growth in Pakistan; An Econometric Approach 8th International Conference 1-3 November 2010., www.umconference.um.edu.my Kuala Lumpur, Malaysia.

TAYLOR, J. (1996): Regional Problems and Policies: A European Perspective Australasian Journal of Regional Studies 2 (2): 103-131.

TóTH, G. (2003): Területi autokorrelációs vizsgálat a Local Moran I módszerével Tér és Társadalom 17 (4): 39-49.

TUHARSKA, E. (1998): Investicna teoria a politika Ekonóm, Bratislava

VALADKHANI, A. (2003): The causes of Unemployment In Iran: an empirical investigation. International Journal of Applied Business and Economic Research 1 (1): 21-33.

Vojtovich, S. (2013): The Impact of Emigration on Unemployment in Slovakia. Inzinerine Ekonomika-Engineering Economics 24 (3): 207-216.

ZOMBORI, GY. (1997): A szociálpolitika alapfogalmai Társadalompolitikai olvasókönyvek Hilcher Rezső Szociálpolitikai Egyesület-ELTE Szociológiai Intézet, Budapest.

\section{INTERNETES HIVATKOZÁS}

DARÓK, I. (2006): Szegények, munkanélküliek, hajléktalanok http://mek.niif.hu/03400/03477/pdf/3_szegeny.pdf (letöltés ideje: 2016. január) 